\title{
Graduate Employability and Communication Skills: An Investigation of Nigerian Graduates' Proficiencies and Areas of Deficiencies in Written English
}

\author{
Toyese Najeem Dahunsi ${ }^{1, *}$ \\ ${ }^{1}$ Department of General Studies, Federal Polytechnic, Ile-Oluji, Ondo State, Nigeria \\ *Correspondence: Department of General Studies, Federal Polytechnic, Ile-Oluji, Ondo State, Nigeria. Tel: \\ 234-802-680-8055. E-mail: deoladahunsi@gmail.com
}

Received: July 16, 2017

doi:10.5430/wjel.v7n3p49
Accepted: August 11, 2017 Online Published: Sptember 27, 2017

URL: https://doi.org/10.5430/wjel.v7n3p49

\begin{abstract}
Nigeria is a West African country with English as second and official language. In this study, the proficiency levels of graduates of Nigeria's higher educational institutions in English were investigated against ever-rising speculations that such graduates were unemployable because they do not have good communication and other employability skills. Essays written by 150 graduate job applicants were used for the research. Error Analysis was used for the identification and categorisation of errors in each essay, using grammar, lexis, punctuation and content as major categories. The first group identified (67\%) had Low Proficiency Level, with poor knowledge of English grammar and grammatical applications; low vocabulary and high deficiencies in lexical selections; poor skills of punctuation, capitalisation, spelling, paragraphing and lettering; and shallow knowledge of common issues. The second group (23\%) had High Proficiency Level, having fewer errors of grammar, lexis, punctuation and content relevance, adequacy, cohesion and coherence. The third group (10\%) had Very High Proficiency Level, with a better mastery, understanding and applications of grammatical, lexical, punctuation and associated composition principles. A poor performance carry-over pattern in English at secondary school level was observed. This calls for serious remedial intervention by Government and all stakeholders to improve graduate employability.
\end{abstract}

Keywords: employability skills; communication skills; English language proficiency; error analysis; grammar; lexis; punctuation

\section{Introduction}

\subsection{Background}

Graduate employability has continued to attract more attention from scholars and policy makers globally. In its report, the (British) Council for Industry and Higher Education (2008, p. 1) notes that notwithstanding the efforts of universities to help students better understand and articulate their skills, "it would appear that many employers are not satisfied with the skills graduate bring to the workplace". It was further reported that $30 \%$ (out of 233) employers have problems with graduate generic employability skills such as team working, communication and problem solving. Among others, Lim (2010), Akanmu (2012), Pitan, and Adedeji (2012), Sodipo (2014), Adebakin, Ajadi and Subair (2015), Pitan (2010, 2015), have investigated the issue of graduate employability and the generic skills expected of graduates both globally and in specific national contexts.

Although the number of studies in the area of graduate employability has continued to sour globally, a plethora of these studies are largely concurrent on what constitutes graduate employability skills. In addition to technical competence in areas of studies, graduates are expected to have what Akanmu (2012) calls life skills, which include problem solving skills, reflective and critical thinking skills, interpersonal and team-building skills, effective communication skills, etc. Akerele and Opatola (2004) aver that in addition to academic qualifications of graduates, there are non-academic skill requirements, which included good personal and social skills, analytical skills, communication skills, among others. 
Almost all previous studies and reports on graduate employability and employability skills identify communication skill as fundamental (Council for Higher education and Industry, 2008; Olusoji \& Magbagbelola, 2005; Lim, 2010; Akanmu, 2012; Pitan \& Adedeji, 2012; Sodipo, 2014; Pitan, 2015). In the context of Nigeria, communication skill is essentially about graduates' proficiency in the use of English for speaking, writing, reading and listening, because English is the official language in the country. In this study, graduates' communication skills in written English were investigated with the aim of determining their proficiency levels and the implications of the varying proficiency levels on their employability.

\subsection{English Language in Nigeria}

The English language is, no doubt, a global language spoken in most countries of the world. According to Crystal (2003, p. 6), about a quarter of the world's population is already fluent or competent in English, and this figure is readily growing. English as a global language has different statuses across the globe. English is the Mother-tongue in some countries (such as Britain, Ireland, Canada, Australia, New Zealand). It is an official language in some countries (including Nigeria, India, Singapore, Ghana). In some countries where English is neither the Mother-tongue nor an official language, it is accorded some priority in the foreign-language teaching policy (e.g. China, Russia, Germany, Spain, Egypt, etc.).

Nigeria is one of the countries where English is not a Mother-tongue but an official language. Though the geographical entity called Nigeria came to being after the amalgamation of the Northern and Southern protectorates by the British colonialists in 1914, English as a foreign language has been in existence within the areas since the nineteenth century (Banjo, 1996). Banjo (1996, p. 1) submits that:

... the English language had, in fact, been taught institutionally in the area now known as Nigeria from about the middle of the nineteenth century, in such institutions as the Hope Waddell Institute, Calabar, the C. M. S. Grammar School, Lagos ... Moreover, there are records attesting to the presence of the language in the same area since the eighteenth century.

For Spencer (1971), the earliest contact with English in the areas called Nigeria was through traders along the West African coast in the sixteenth century. Since then, English has been tremendously influenced by such agencies as commerce, religion and education (Banjo, 1996). Nigeria is one of the former West African colonies of Britain. As a result, it has adopted and continued to retain English as its official language. English, for many pre and post-independence years in Nigeria, was regarded as the language of the educated elite. However, Jowitt (2013) avers that the position of English in Nigeria is becoming steadily stronger, and maintained further, citing Schneider (2007), that there is "increasing number of young Nigerians who for various reasons learn English before they learn any other languages", (Jowitt, 2013, p. 3).

English has, therefore, attained a special position in Nigeria, as it is not only used for official purposes but also for various unofficial functions and activities (including casual interactions, informal commercial transactions, worships and prayers, ceremonies, etc.). Taiwo (2009) observes that English is no longer restricted to educated Nigerians, and notes further that even the uneducated make efforts to speak it. Because English is the official language in Nigeria, it is, resultantly, the language used as medium of instruction in schools, especially at post-primary level. In view of this status and enormous importance, English is taught as a compulsory subject at all levels of both primary and secondary education in Nigeria. At the tertiary educational level, all Higher Educational Institutions (HEIs) in the country ensure a mandatory registration for, and pass in, an introductory course in English, with the principal objective of preparing students for effective learning through effective communication in English.

Banjo (1996) traced the practice of a mandatory course in English in Nigeria's HEIs to the mid 1960's when after four years of full autonomy status, the first University in Nigeria, the University of Ibadan, observed students' slow reading habits in the Faculty of Arts. Banjo (1991, p. 52) reports that "at a time when the reading speed of the average American undergraduate was estimated to be about 400 words per minute, that of the average Ibadan Arts undergraduate was found to be as slow as 176". He reports that the observation led to the establishment of the Reading Centre in 1966 with the support of Rockefeller Foundation of America to remediate the observed reading deficiencies. He further reports:

No sooner was training in reading remediation begun at the Reading Centre, however, than other underlying language deficiencies began to reveal themselves. Gradually, the Centre expanded its activities to include training in the other language skills - in writing, listening comprehension and in speaking ... Now, all Nigerian universities offer a General Studies programme, at the heart of which lies a developmental course in English (Banjo, 1991, p. 53). 
In most HEIs, the English proficiency and/or communication skills course is run as a general studies programme, thus making it one of the mandatory academic requirements for graduation. Every graduate of any of Nigeria's HEIs is expected to have taken courses in English for a minimum of thirteen years (six at the primary level, six at the secondary level and a one-year developmental course at the tertiary level). Degree programmes are also run in English Language in most HEIs for qualified candidates in art and the humanities, which takes a minimum of three full years for graduation.

The enormity of the role and importance of English as an official language and means of communication makes it a fundamental requirement for job placement at all levels of government and the industrial sector. This is why the employers of labour often attach great importance to job applicants' communication skills (spoken and written) in English.

\subsection{Statement of the Research Problem}

In the last two decades, graduates of Nigeria's HEIs have often been negatively described in terms of their quality when compared to early post-Independence graduates and their counterparts in other parts of the world. In a newspaper article (The Guardian of $5^{\text {th }}$ November, 2015), the author describes graduates of Nigeria's HEIs as certified illiterates and unemployable graduates, noting further that graduates of Nigeria's HEIs were not employable because they lacked employability skills. One of the skills often complained about is the communication skill of such graduates, undoubtedly, their ability to use English proficiently. This study was therefore conducted in order to investigate the proficiency levels of selected graduates of Nigeria's HEIs in English with a view to corroborating or refuting the various views on the communication skills of graduates of Nigeria's HEIs in English.

\subsection{Literature Review}

Employability skills have been identified to include communication skills, analytical cum problem solving skills, critical thinking skills, Information Technology skills, numeracy skills, among numerous others (Pitan, 2015; Lee \& Edwards, 1997; Lim, 2010; Akanmu, 2012; Pitan \& Adedeji, 2012; Sodipo, 2014). With the identification of these employability skills required of graduates of HEIs globally, scholars have investigated employers' perception of graduates (Pitan, 2015; Pitan \& Ayodeji, 2012; Akanmu, 2012; Lim, 2010; Sodipo, 2014). Pitan (2015) examined selected organisations' demand for generic skills and determined the importance of, and preference for each generic skill in five sectors of the Nigerian economy (manufacturing, agriculture, health, banking and education). It was reported that there was a significant difference in the demand for each of the skills among the five sectors, with the implication that the degree to which each of the skills is important differs across the different sectors. The study also reported cross-sectoral preference for communication skills as being among the topmost priorities.

Adeyemo, Ogunleye, Oke and Adenle (2010) undertook a survey of factors that determined the employability of science and technology graduates of polytechnics and universities in the Nigerian labour market. Through the administration of structured questionnaires among selected employers and employees and the analysis of the information collected, they reported "a large mismatch between university outputs and labour market demands" (Adeyemo et al, 2010, p. 1). Some of the labour market demands and expectations from graduates were enumerated to include: subject specific skills, graduates' communication skills, problem solving skills, Information and Communication Technology skills, etc.

Akanmu (2012) expresses immense concern on the constantly increasing graduate turn-out from Nigeria's HEIs against the consistent decline in the employability of such graduates. It was reported that many graduates could not find jobs because employers wanted their employees to be technically competent in their chosen field, and to possess complementary life skills including effective communication, reflective and critical thinking skills, which graduates of Nigeria's HEIs largely did not possess. Pitan and Adedeji (2012) investigated what they call "skills mismatch" and its prevalence in the Nigerian labor market. It was found in the study that there was a significant negative relationship between skills demand and supply, and the extent of skills mismatch was $60.6 \%$. They submit that the major weaknesses were found in communication, IT, decision making, critical thinking and entrepreneurial skills.

There have also been a plethora of studies on writing in an L2 environment. Some of these studies have identified different levels of writing proficiency among English L2 users, with varying features and characteristics for each level of proficiency identified (Ferris, 1994; Jarvis, Grant, Bikowsky \& Ferris, 2003; Crossly, Salsbury \& McNamara, 2012). Studies have also reported significant differences in writing in a first and second language situations (Sylvia, 1993). The significance of the current study lies in the fact, first, that as against most of other studies that have investigated graduate employability by sampling employers' opinions on the graduate employees, this study directly assessed the language output of graduates with a view to technically determining their proficiencies. Second, as most 
of the existing studies on L2 writing have largely been at below graduate level, this study examined the use of English in writing by people who have had a minimum of thirteen years continuous contact with English as a compulsory subject as a medium of instruction in their education levels.

\section{Materials and Methods of Analysis}

Selected graduates of some of Nigeria's HEIs who were looking for jobs were used for the study. A public organisation advertised some vacancies and over 10,000 applications were submitted in response to the advert. One of the positions advertised was Administrative Officer II, with a good first degree as qualification. A total of 1,500 graduates applied for this position. As part of the procedures for shortlisting, a written test was organised for the applicants. The test consisted of a 1,500 word essay on unemployment in Nigeria. The subjects were given the same time to write the test, and none of them had prior knowledge of the test before the time. After the test, a total of 150 scripts were randomly selected for assessment and evaluation. The research data therefore consisted of the written English of each of the selected subjects, which was used to assess the subjects' levels of proficiencies and areas of deficiencies.

The analytical model adopted for the study is Error Analysis (EA). The word "error" in language studies has been defined as "a noticeable deviation from the adult grammar of a native speaker" (Brown, 1994, p. 205). Being a common and frequent feature of second language learning, errors have continued to attract the attention of a great percentage of linguists. Resultantly, EA emerged in the 1960s (traceable to Coder, 1967; 1971) principally for the identification, classification, evaluation and correction of errors arising from the influence of native language on second language learning. According to Sompong (2014),

Conducting error analysis is therefore one of the best ways to describe and explain errors committed by L2 learners. This kind of analysis can reveal the sources of these errors and the causes of their frequent occurrence. Once the sources and causes are revealed, it is possible to determine the remedy, as well as the emphasis and sequence of future instructions (p. 110).

Each subject's proficiency and areas of deficiencies were assessed using four parameters, which included grammar, lexis, content and punctuation. For each of these, there were sub-parameters. Under grammar, each subject's proficiency and deficiencies were critically examined in the areas of tense (in terms of proper and improper use of tenses - present, past, continuous); concord (in terms of singularity and plurality of nouns, and subject-verb agreements); sentence formation skills (the completeness and accurate punctuation of sentences); parts of speech (in terms of the appropriacy or otherwise of the various parts of speech in sentences) and articles (that is how each subject was able to use the articles the, $a$, and $a$ in the written piece).

Under lexis, the foci of assessment were on lexical appropriacy (that is correctness and incorrectness of word use in specific contexts); lexical diversity (in terms of token-type ratios of words); figurative use of language (that is, each subject's knowledge and use of idioms, proverbs and quotations); lexical interference (that is, how each subject's native language interfered in their use of words in English). For content, the foci of assessment were the relevance of the write-up to the topic, the adequacy of the write-up in terms of length, use of cohesive devices to achieve unity, and coherence. In terms of punctuation, the assessment focus was on the use of punctuation marks, knowledge and application of capitalisation skills, paragraphing techniques, spelling and lettering pattern (with respect to the conformity or otherwise with established writing conventions). These are presented in Table 1. At the end of the assessment for each essay, the various errors were categorised into grammatical, lexical, content and punctuation. 
Table 1. Parameters for Assessment of Essays

\begin{tabular}{|c|c|c|}
\hline $\begin{array}{l}\text { Error } \\
\text { Categories }\end{array}$ & Error Types & Criteria for Assessment \\
\hline \multirow{6}{*}{ Grammar } & Tense & $\begin{array}{l}\text { Frequencies of errors in the use of the present, past and } \\
\text { continuous tenses. }\end{array}$ \\
\hline & Concord & $\begin{array}{l}\text { Frequencies of errors in the use of singular nouns and verbs } \\
\text { versus plural nouns and verbs. }\end{array}$ \\
\hline & Sent. Formation & $\begin{array}{l}\text { Completeness of sentences, correct use sentence types: simple, } \\
\text { complex, compound, multiple sentences. }\end{array}$ \\
\hline & Parts of speech & Knowledge and correct use of the various parts of speech. \\
\hline & Articles & Knowledge and correct use of articles the, an, and $a$. \\
\hline & Appropriacy & Correct and incorrect use of words generally \\
\hline \multirow{3}{*}{ Lexis } & Diversity & Ratio of word types versus word tokens; richness of vocabulary \\
\hline & Fig. expressions & Use of idioms, figures of speech and proverbs \\
\hline & Lexical interference & $\begin{array}{l}\text { Transfer of lexical features of local language to English and use } \\
\text { of local word equivalents in place of correct English words }\end{array}$ \\
\hline \multirow{3}{*}{ Content } & Relevance & Relevance of essay to the topic given \\
\hline & Adequacy & Whether (or not) the essay is up to the required quantity \\
\hline & Cohesion & $\begin{array}{l}\text { Linking of all parts of the write-up to one another to achieve } \\
\text { unity }\end{array}$ \\
\hline \multirow{6}{*}{ Punctuation } & Coherence & Logicality of inherent ideas in the essay \\
\hline & Punctuation skills & $\begin{array}{l}\text { Use of standardised non-alphabetical symbols to organise essays } \\
\text { into clauses, phrases and sentences, i. e. correct or incorrect use } \\
\text { of punctuation marks }\end{array}$ \\
\hline & Capitalisation & $\begin{array}{l}\text { Application of capitalisation skills to proper nouns, sentence } \\
\text { beginnings, etc. }\end{array}$ \\
\hline & Paragraphing styles & Knowledge and application of paragraphing skills to essay \\
\hline & Spelling & Correct and incorrect spelling of words \\
\hline & Lettering pattern & Conformity of writings to conventional styles \\
\hline
\end{tabular}

\section{Results and Discussion}

\subsection{Subjects' Performances under Grammar}

After a critical assessment and marking of the 150 scripts, the various performances and frequencies of error types were collated based on each parameter. Presented in Table 2 are the performances of subjects under grammar. As the table shows, the frequencies of errors by the 150 subjects vary significantly from parameter to parameter. In the area of tense, out of the 150 scripts, none of the subjects had error-free essays. Every script assessed contained or tense one error or the other with frequencies ranging from 5 to 8 errors (only 15 subjects, that is $10 \%$ ); 9 to 12 errors ( 33 subjects, that is $22 \%$ ); 13 to 15 errors (48, that is $32 \%$ ) and errors above 15 (54, making $36 \%$ ). For number and concord, only 1 out of the 150 subjects had error-free essay. 15 subjects had between 5 and 8 errors (that is, $10 \%$ ); 35 subjects had between 9 and 12 errors (23\%); 45 had errors ranging from 13 to 15 (30\%); while 54 (36\%) had errors above 15.

In terms of sentence formation errors, only 1 subject had errors ranging from 0 to $4 ; 10$ subjects $(15 \%)$ had $5-8$ errors; 34 (23\%) had 9 to 12 errors; 49 (33\%) had errors ranging from 13 to 15; while 56 (37\%) had errors above 15. Only 1 subject had $0-4$ errors in the use of articles the, an and $a .13(9 \%)$ had errors ranging from 5 to $8 ; 34(23 \%)$ had errors ranging from 9 to 12; 49 (33\%) had errors between 13 and 15; while $56(37 \%)$ had errors above 15. In the appropriacy or otherwise of the various parts of speech, only 1 subject had errors below $4.15(10 \%)$ subjects had between 5 and 8 errors; 38 (25\%) had between 9 and 12 errors; 47 (31\%) had errors ranging from 13 to 15; while 49 
(33\%) had errors above 15 . These varying frequencies are graphically presented in Fig. 1.

Table 2. Frequencies of Grammatical Errors in the Assessed Scripts

\begin{tabular}{llllllllll}
\hline Error Types & $\begin{array}{l}\mathbf{1}-\mathbf{4} \\
\text { errors }\end{array}$ & $\begin{array}{l}\mathbf{5}-\mathbf{8} \\
\text { errors }\end{array}$ & $\begin{array}{l}\mathbf{9}-\mathbf{1 2} \\
\text { errors }\end{array}$ & $\begin{array}{l}\mathbf{1 3}- \\
\text { errors }\end{array}$ & $\begin{array}{l}\text { Above } \\
\text { errors }\end{array}$ \\
\hline \multirow{6}{*}{ Grammar } & Tense & 0 & 15 & 33 & 48 & 54 & \\
& Concord & 1 & 15 & 35 & 45 & 54 & \\
& Sent. Formation & 1 & 10 & 34 & 49 & 56 & \\
& Articles & 1 & 13 & 26 & 49 & 61 & \\
& P. of Speech & 1 & 15 & 38 & 47 & 49 & \\
\hline
\end{tabular}

From the results presented above, it is easy to note that majority of the scripts contained a large number of grammatical errors. Every script had one grammatical error or the other. Out of the 150 scripts, only a maximum of 16 (representing 11\%) had errors between 1 and 8 for each grammatical category investigated. The remaining $89 \%$ had more errors than 8 in each case, thus indicating significant grammatical deficiencies for majority of the subjects.

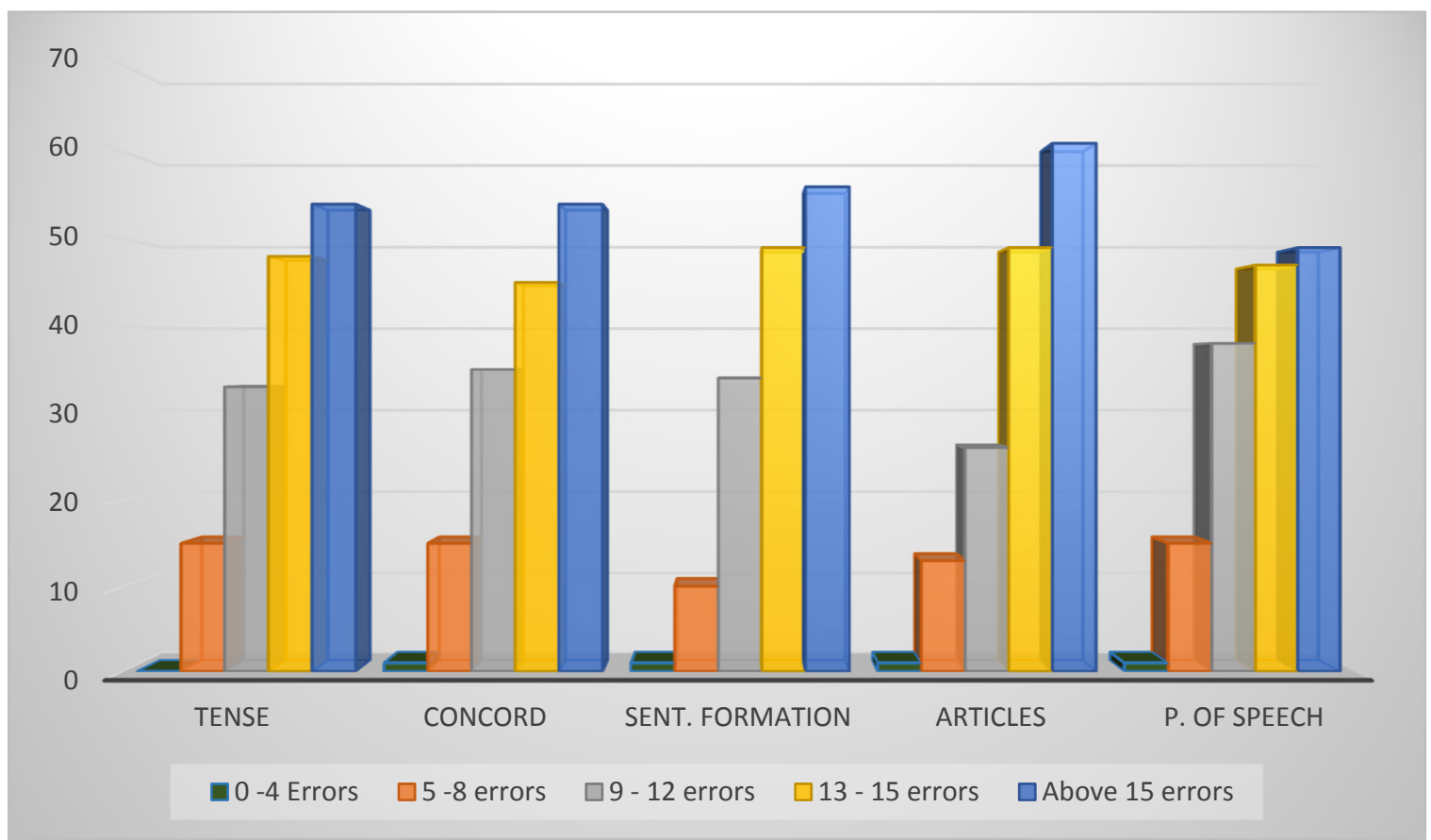

Figure 1. Frequencies of Grammatical Errors in the 150 Scripts Assessed

\subsection{Subjects' Performances under Lexis}

Table 2 shows the varying frequencies of the error types under lexis. The error types here were in the areas of lexical appropriacy, lexical diversity, figurative expressions and lexical interference. Lexical appropriacy assessment was based on correct or incorrect use of words in contexts. For example, a subject wrote Democratic structure in Nigeria is contain of legislature... and democracy as been be happen in Nigeria. In these examples, the words contain, as, been, be, happen were all incorrectly used. The assessment of lexical diversity in each essay was done by critically looking at the vocabulary and finding out the frequencies of word types against word tokens. The volume of each essay was also considered in the determination of this. In the assessment for figurative, idiomatic and proverbial use of language, the availability and number of figures of speech, idiomatic expressions and proverbs were critically 
examined in each essay. Errors of lexical interference included what Akindele and Adegbite (1999, p. 41) called semantic contrast, semantic extension, semantic transfer and coinages.

Table 3. Performances of Subjects across Lexical Variables

\begin{tabular}{llcccccc}
\hline \multirow{2}{*}{ Lexical errors } & Error types & $\begin{array}{c}\mathbf{0 - 2 0} \\
\text { marks }\end{array}$ & $\begin{array}{c}\mathbf{2 1 - 4 0} \\
\text { marks }\end{array}$ & $\begin{array}{c}\mathbf{4 1 - 6 0} \\
\text { marks }\end{array}$ & $\begin{array}{c}\mathbf{6 1 - 8 0} \\
\text { marks }\end{array}$ & $\begin{array}{c}\mathbf{8 1 - 1 0 0} \\
\text { marks }\end{array}$ & Total \\
\cline { 2 - 7 } & Appropriacy & 41 & 49 & 39 & 19 & 2 & 150 \\
& Diversity & 46 & 52 & 36 & 16 & 0 & 150 \\
& Fig. expressions & 55 & 64 & 26 & 5 & 0 & 150 \\
& Interference & 48 & 64 & 28 & 10 & 0 & 150 \\
\hline
\end{tabular}

As the results of analysis above show, majority of the subjects had numerous errors associated to vocabulary. In terms of how correctly or appropriately words have been used in contexts, a total of $90(60 \%)$ fell below $40 \%$ (40 scoring 0 to 20 marks, 49 scoring 21 to 40 marks). These errors were indicative of vocabulary development deficiencies among the subjects. Only 60 of the subjects scored between 41 and 100. Within this performance bracket, 39 scored 41 to 60,19 scored 61 to 80 , while only 2 scored between 81 and 100 . For lexical diversity, that is, how rich the vocabulary of each subject was, majority of the subjects showed evidence of shallow vocabulary. 98 subjects (representing 65\%) scored between 1 and 40 marks (46 scored 0-20 marks, while 52 scored 21 to 40 marks). Only 52 of the subjects performed fairly well by showing some evidence of diversified vocabulary. Among these, 36 scored 41 to $60 \%$, while 16 scored between 61 and $80 \%$.

More than two-third of the subjects had problems relating to the use of figurative expressions, idioms and proverbs. Among these, a total of 55 (representing 37\%) did not use any of figurative expressions, idioms and proverbs throughout their essays. A total of 64 (that is, 43\%) either had very low use of these figurative and idiomatic expressions or used them inappropriately in context. Only 31 (that is 21\%) had good instances of figurative, idiomatic and proverbial expressions in their essays. Lastly, in terms errors relating to lexical interference, which were conspicuous transfer or influence of ideas from local cultures and languages to English, $112(75 \%)$ scripts had instances of this. It was only in 38 cases that the inter-mix of subjects' local languages with English was not conspicuous. These varying performances are graphically presented in Fig. 2.

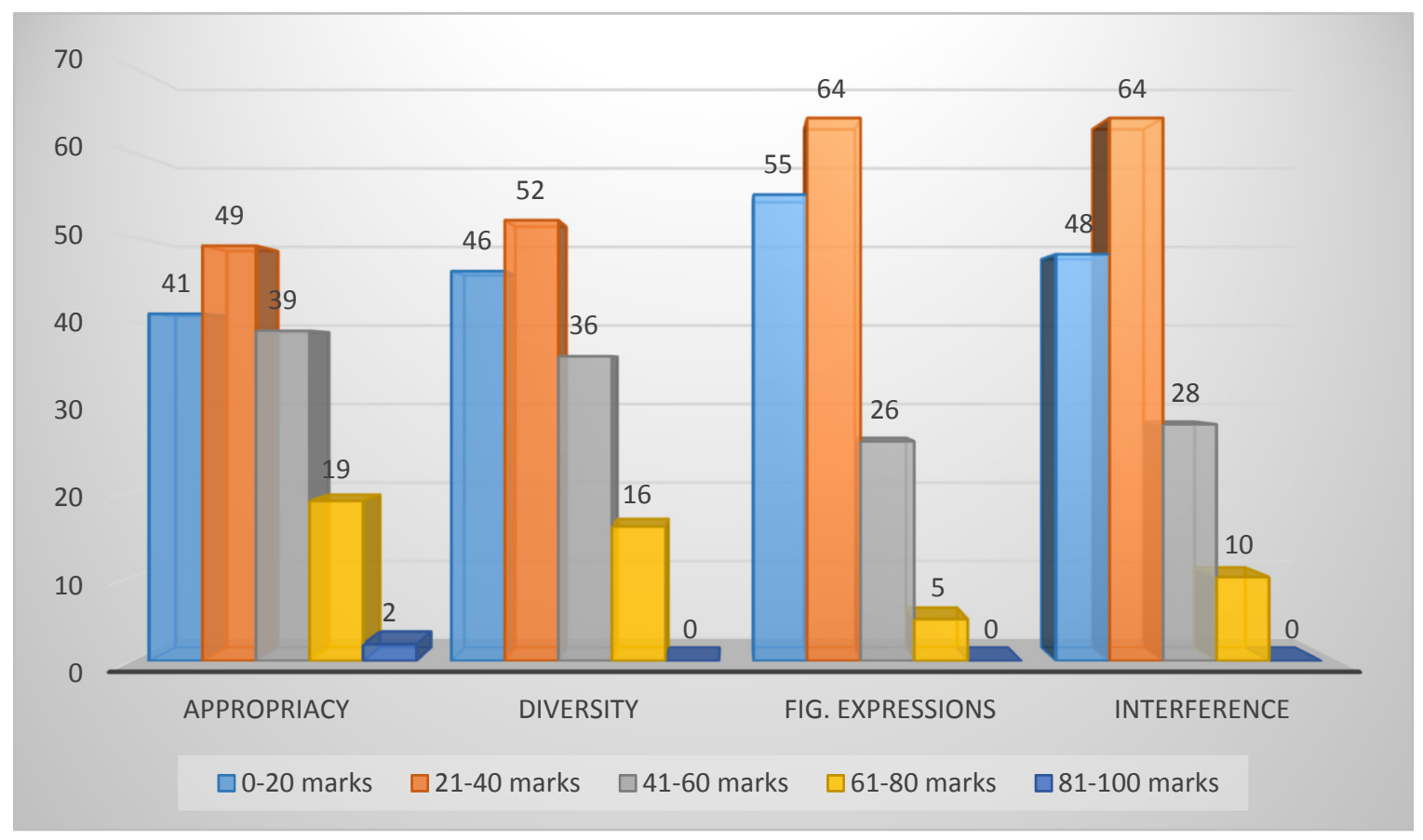

Figure 2. Results of Assessment under Lexis 
Following from the results, in the area of lexis and vocabulary development and application, it is easy to conclude that majority of the subjects had problems of lexical selections and vocabulary development, which led to their largely inappropriate use of words and shallow vocabulary. A large majority of the subjects were also not familiar with figures of speech, idioms and proverbs, and could, consequently not use them at all or where they used them, they did incorrectly. In addition, the language of the majority of the subjects was seen to be largely characterised by the interference of lexical features of subjects' local languages on English.

\subsection{Subjects' Performances under Punctuation}

With regard to punctuation and associated errors, there were five types investigated. These included appropriate or inappropriate use of punctuation marks, capitalisation skills, paragraphing style, spellings and lettering pattern. The various errors and respective types were categorised in ranges, with details shown in Table 4.

Table 4. Frequency of Punctuation Errors in the Assessed Scripts

\begin{tabular}{llllllll}
\hline \multirow{2}{*}{ Error types } & $\begin{array}{l}\mathbf{1 - 5} \\
\text { errors }\end{array}$ & $\begin{array}{l}\mathbf{6 - 1 0} \\
\text { errors }\end{array}$ & $\begin{array}{l}\mathbf{1 1 - 1 5} \\
\text { errors }\end{array}$ & $\begin{array}{l}\mathbf{1 6 - 2 0} \\
\text { errors }\end{array}$ & $\begin{array}{l}\text { Above } \\
\text { errors }\end{array}$ & Total \\
\cline { 2 - 7 } Punctuation & Punctuation marks & 1 & 5 & 22 & 59 & 63 & 150 \\
errors & Capitalisation & 0 & 13 & 33 & 49 & 55 & 150 \\
& Paragraphing & 4 & 21 & 25 & 52 & 48 & 150 \\
& Spellings & 2 & 18 & 34 & 46 & 50 & 150 \\
& Lettering & 2 & 17 & 38 & 52 & 41 & 150 \\
\hline
\end{tabular}

The results above show that none of the 150 scripts was error-proof in terms of the use of punctuation marks, the capitalisation of sentence beginnings, abbreviations and proper nouns, the conformity of paragraphing style to established conventions, spelling of words and lettering system. In the correct use of punctuation marks (full-stop, comma, colon, semi-colon, apostrophe, etc.), only 6 of the subjects had a maximum of 10 errors. The remaining subjects had errors ranging from 11 to above 20. Within this bracket, a total of 63 (42\%) had more than 20 punctuation errors each, thus implying that they were not familiar with punctuation marks at all, they used far less punctuation marks than required or largely used punctuation marks incorrectly. A total of 59 (39\%) showed evidence of familiarity with punctuation marks, but used the marks both incorrectly and far less than required.

The results also showed that majority of the subjects lacked capitalisation skills. A total of $104(69 \%)$ had more than 15 capitalisation errors in their respective scripts, an indication that they did not know what capitalisation entailed, how and where to capitalise words. Majority of the subjects also showed poor paragraphing skills in the scripts. A total of 48 subjects (32\%) either did not write in paragraphs at all or did not properly indicate paragraph beginnings and endings. $52(35 \%)$ subjects wrote in far less paragraphs than required and often did not get the indentation correctly done. $50(33 \%)$ other subjects had errors having to do with information structure and organization in paragraphs as well as the length of paragraphs. Sometimes too, these category of subjects confused the block paragraphing format with the indentation format.

Word spelling is another area where majority of the subjects exhibited low mastery and skills. Spelling problems occurred largely as a result of subjects' inability to write the correct spellings of words and inability to distinguish between the British and the American spellings of words. A total of $50(33 \%)$ subjects had spelling errors above 20 in their respective essays. 46 subjects $(30 \%)$ had between 16 and 20 spelling errors, while 54 subjects had between 1 and 15 errors of spelling. This shows that an overwhelming majority of the subjects were deficient in spelling. Lastly, lettering errors were errors of improper writing of alphabets in such ways that made the alphabets unconventional in appearance. In this error type, the first category of subjects was those who had more than 20 instances of miswritten alphabets, being 41 (27\%). This is followed by those with errors ranging between 16 and 20 (52, representing 35\%); and then those with 11 to 15 instances of miswritten alphabets (38, representing 25\%). Only 19 of the subjects had errors of spelling below 10. The varying error frequencies under punctuation are graphically presented in Fig. 3. 


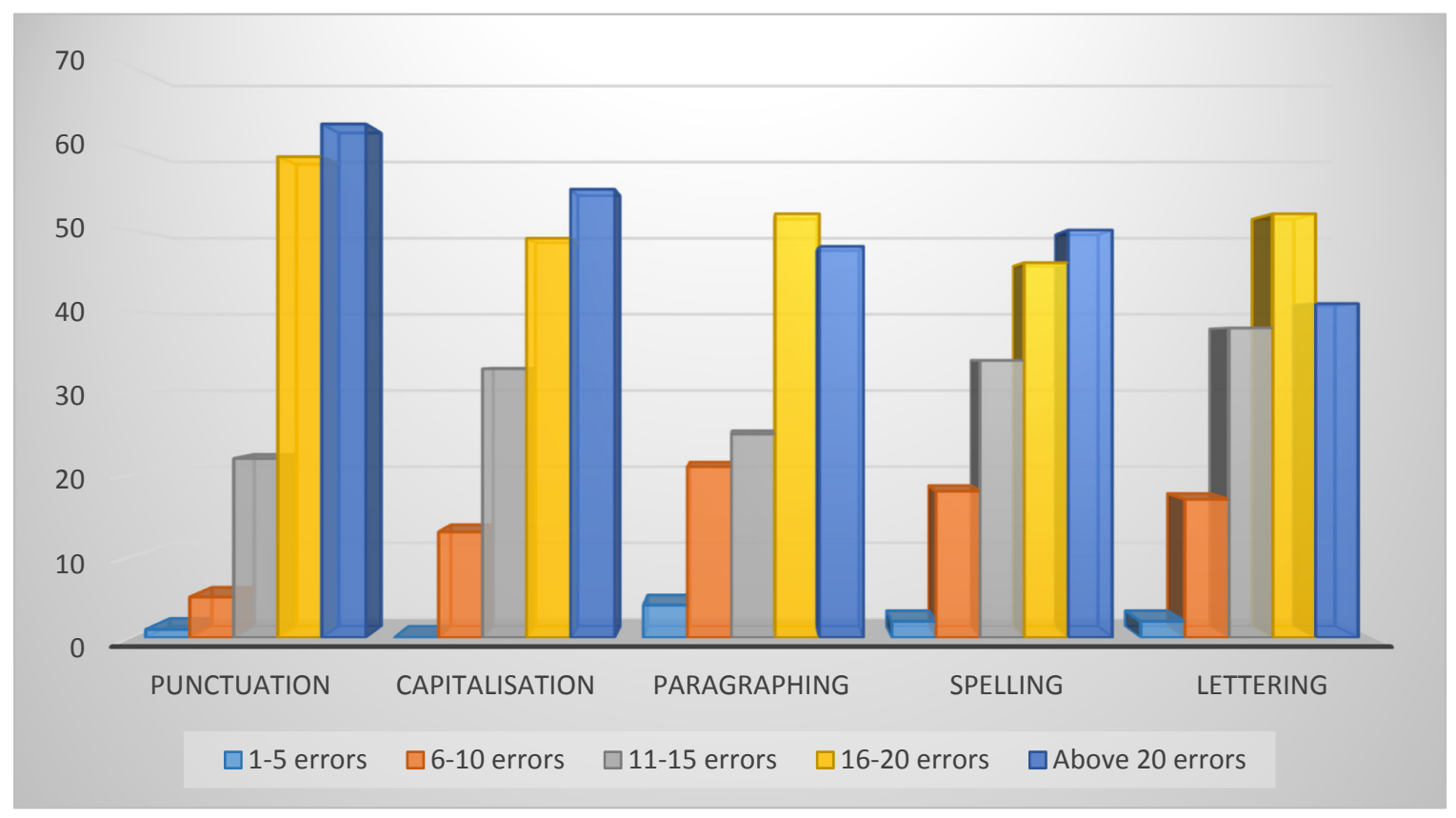

Figure 3. Frequencies of Punctuation and Related Errors in the 150 Scripts Assessed

What the various error frequencies under punctuation suggest is that majority (more than half in each case) of the subjects exhibited high level of deficiencies in the use of punctuation marks, capitalisation, paragraphing skills, spelling and conventional lettering system.

\subsection{Subjects' Performances under Content Analysis}

The last area investigated in the study was the content of each essay. Bearing in mind that the topic of essay for all subjects was unemployment in Nigeria, the assessment of the quality, quantity and unity of essays was done by an assessment of the adequacy of the essay vis-à-vis the expected length of 1,500 words; the relevance of the essay to the topic of discourse; as well as the degrees of cohesion and coherence in each essay. Each of these items was scored over hundred after a very painstaking consideration. The subjects' scores under content assessment are shown in Table 5.

Table 5. Performances of Subjects in Content Variables

\begin{tabular}{llllllll}
\hline \multirow{2}{*}{ Focus } & $\mathbf{0 - 2 0}$ marks & $\begin{array}{l}\mathbf{2 1 - 4 0} \\
\text { marks }\end{array}$ & $\begin{array}{l}\mathbf{4 1 - 6 0} \\
\text { marks }\end{array}$ & $\begin{array}{l}\mathbf{6 1 - 8 0} \\
\text { marks }\end{array}$ & $\begin{array}{l}\mathbf{8 1 - 1 0 0} \\
\text { marks }\end{array}$ & Total \\
\cline { 2 - 7 } Content & Adequacy & 41 & 55 & 39 & 14 & 1 & 150 \\
& Relevance & 29 & 45 & 49 & 24 & 3 & 150 \\
& Cohesion & 39 & 52 & 43 & 15 & 1 & 150 \\
& Coherence & 35 & 59 & 40 & 15 & 1 & 150 \\
\hline
\end{tabular}

As the scores above show, more than half of the subjects scored below $40 \%$ in each of the areas of focus. In terms of the quantity and adequacy of the essays, a total of 41 (that is, 27\%) subjects wrote between 1 and 300 words; 55 (37\%) subjects wrote between 301 and 600 words; 39 (26\%) wrote between 601 and 900 words; 14 (9\%) wrote between 901 and 1200 words; while only 1 subject wrote between 1201 and 1500 words. These show that majority of the essays were grossly inadequate, an indication that majority of the subjects were not knowledgeable in the common subject-matter. In terms of the relevance of essays to the topic given, only 27 essays could be adjudged to be sufficiently relevant to the topic (only 1 scored between 81 and 100; 24 scored between 61 and 80 ). For all others, the degrees of relevance varied significantly from those whose write-ups were outrightly irrelevant or tangentially relevant (29, i.e. $19 \%$ who scored from 1 to 20$)$; to those whose essays were fairly relevant ( 45 , i.e. $30 \%$ who scored 21 to 40 ) and those whose write-ups were averagely relevant (49, i.e. $33 \%$ who scored between 41 and 60 ). 
The assessment of cohesion was done by examining how component parts and information segments in each essay have been linked together with the use of cohesive ties to achieve unity. The various scores in the table show the five different categories of essays in this regard. The first category comprised subjects whose essays contained complete "stand-alone" chunks of information without any overt inter-sentential relationship (being 39, i. e. 26\%) with scores ranging between 1 and 20. The second category comprised those who used cohesive devices but either used them incorrectly or insufficiently (being 52, i.e. 35\%) with scores ranging from 21 to 40 . The remaining 59 subjects scored between 41 and 100, an indication that there was evidence of unity and cohesion but at varying degrees across the essays. In the same vein, the degree of coherence varied across essays. These ranged from those whose essays were grossly incoherent (35 in all) to those with fair coherence degrees (59 in all) and those with averagely good (40), very good degrees of coherence (15) and exceptionally good degree of coherence (1). The performances of the subjects in content analysis are presented in Fig. 4.

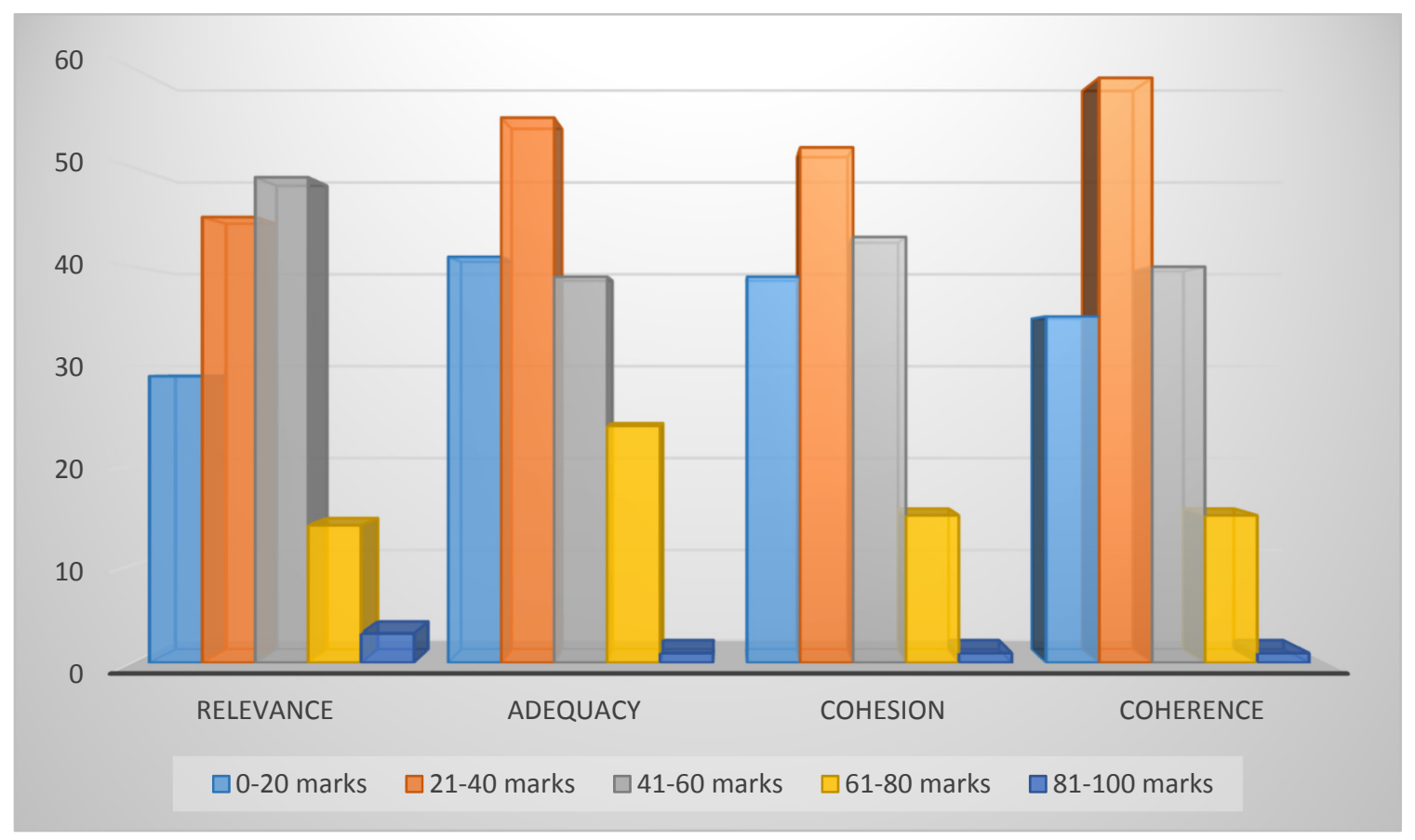

Figure 4. Graphical Presentation of Subjects' Performances in Content Analysis

Based on the various scores above, it can be deduced that majority of the subjects lacked in-depth subject-matter knowledge (which affected their adequacy and relevance across essays); and they lacked information presentation and organisation skills (which affected their degrees of cohesion and coherence across essays).

\subsection{Determination of Subjects' Proficiency Levels}

For the purpose of this study, three distinct levels of proficiency were defined. These were: low proficiency level, high proficiency level and very high proficiency level. To determine the subjects' levels of proficiency, each of the error types were converted to percentage scores for each subject and the averages for all were worked out for each of the four major categories of error. Based on performance percentages, overall performances between $1 \%$ and $40 \%$ were classified as low proficiency in written English; performances between $41 \%$ and $60 \%$ were classified as high proficiency in written English; while performances between $61 \%$ and $100 \%$ were classified as very high proficiency level in written English. This is shown in Table 6 below. 
Table 6. Classification of Subjects into Proficiency Levels

\begin{tabular}{lllll}
\hline & $\begin{array}{l}\text { Average on 1-40\% } \\
\text { (Low Proficiency) }\end{array}$ & $\begin{array}{l}\text { Average on 41-60\% } \\
\text { (High Proficiency) }\end{array}$ & $\begin{array}{l}\text { Average on } \mathbf{6 1 - 1 0 0 \%} \\
\text { (Very High Proficiency) }\end{array}$ & Total \\
\hline Grammar & $102(68 \%)$ & $34(23 \%)$ & $14(9 \%)$ & 150 \\
Lexis & $105(70 \%)$ & $32(21 \%)$ & $13(9 \%)$ & 150 \\
Punctuation & $103(69 \%)$ & $30(20 \%)$ & $17(11 \%)$ & 150 \\
Content & $89(59 \%)$ & $43(29 \%)$ & $18(12 \%)$ & 150 \\
Total Average & $\mathbf{6 7 \%}$ & $\mathbf{2 3 \%}$ & $\mathbf{1 0 \%}$ & \\
\hline
\end{tabular}

The performance averages and the proficiency level classifications presented in Table 6 above show that of the 150 subjects examined, an average of 100 (representing 67\%) fell below $40 \%$ marks overall. This category of subjects fell within Low Proficiency Level in written English. These were subjects whose knowledge of grammar and grammatical applications was found to be very poor; who had very low vocabulary and were found to be deficient in lexical selections; who were found to be lacking punctuation, capitalisation, spelling, paragraphing and lettering skills; and whose knowledge about common issues was found to be very low, thus affecting the adequacy, relevance, cohesion and coherence of their write-ups. A graphical illustration of the three proficiency levels and the percentages of subjects in each category are presented in Fig. 4.

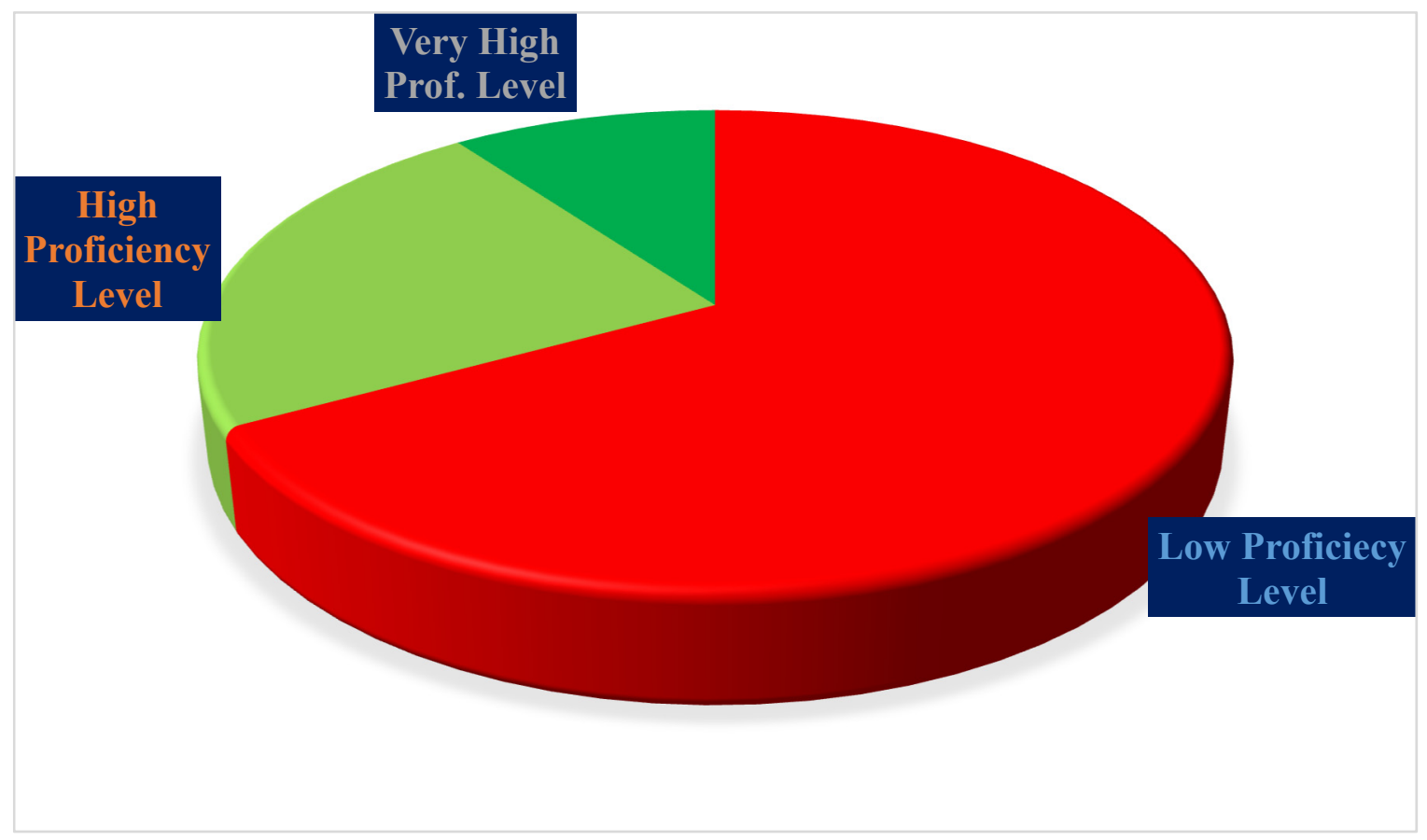

Figure 5. Proficiency Levels of All the 150 Subjects Assessed

Next to this category of subjects were the subjects who fell within the High Proficiency Level in written English. The overall average performances of these subjects ranged between 41 and 60, and they were an average of 34 (representing 23\%). These subjects had fewer errors of grammar, lexis, punctuation and content than those with Low Proficiency Level. They showed fairly good knowledge of grammar, lexis and punctuation, and their understanding of the subject-matter was about average. The last category comprised the subjects classified as having Very High Proficiency Level in written English. These were an average of 16 subjects (representing only 10\%). In most cases, the error ranges of these subjects per parameter were less than 10, and they exhibited a good mastery of grammar, lexis, punctuation and the subject-matter.

The general performance of the subjects (who were graduates of Nigerian universities) followed the same pattern of mass failure and low proficiencies with students who wrote the Senior School Certificate of Examinations at the end 
of their secondary education. For instance, as reported (Vanguard Newspaper, $10^{\text {th }}$ August, 2015), only $38.68 \%$ of $1,593,442$ passed English at credit level, leaving $61.32 \%$ who failed the subject. As further reported, only $31.28 \%$ of total candidates passed English at credit level in 2014; and in 2013, only $38.30 \%$ of the candidates passed the subject at credit level. This carry-over pattern of low proficiency and mass failure from end of secondary education to end of tertiary education is worrisome and should be reversed.

\section{Conclusion and Recommendations}

The proficiency levels and areas of deficiencies of selected graduates of Nigeria's HEIs in written English were investigated and determined. The results of error analysis showed that majority of graduates of Nigeria's HEIs had communication problem as earlier documented by some previous studies (Pitan \& Adedeji, 2012; Sodipo, 2014; Adebakin, Ajadi \& Subair, 2015). 67\% of the subjects scored below $40 \%$ in the assessment conducted. These were classified as subjects with Low Proficiency Level, characterised by poor knowledge of English grammar and grammatical applications; low vocabulary and high deficiency level in lexical selections; poor skills of punctuation, capitalisation, spelling, paragraphing and lettering; and shallow knowledge of common issues, thus resulting in the varying inadequacy, irrelevance, non-cohesion and non-coherence of their write-ups.

The second category of subjects were those with High Proficiency Level (being 23\%). These were subjects with fewer errors of grammar, lexis, punctuation and content relevance, adequacy, cohesion and coherence. The last category were subjects with Very High Proficiency Level (only 10\%), who showed a better mastery, understanding and applications of grammatical, lexical, punctuation and content relevance, adequacy, cohesion and coherence principles. The findings of the study corroborate some earlier studies (such as Kim, 2014) which identified different L2 writing proficiency levels and reported linguistic features that characterise each level of proficiency.

The output of this study calls for remedial intervention by Government, policy makers, managers of higher education and professionals in the teaching of English in Nigeria. The observed performance carry-over pattern from secondary education to tertiary education needs to be worked upon and reversed if the employability of graduates of Nigeria's HEIs is to be improved. One of the critical factors to work on is the communication skill of the graduates, and more importantly, English as a means of official communication. It is therefore recommended that the overall curricula of all HEIs in the country should be overhauled to give more prominence to the teaching and learning of English. In this case, the use of English should be taught beyond the first-year mandatory course. A similar mandatory course in English should be run for all final year students with the sole objective of refining the students' use of English. The recommended language refinement should include some revision on grammar, lexis, punctuation and composition; distinction between formal and informal use of language; course-specific register and language use, among others.

\section{References}

Adebakin, A. B., Ajadi, T. O., \& Subair, S. T. (2015). Required and possessed university graduate employability skills: Perceptions of the Nigerian employers. World Journal of Education, 5(2), 115-121. https://doi.org/10.5430/wje.v5n2p115

Adeyemo, S. A., Ogunleye, A. O., Oke, C. O., \& Adenle, S. O. (2010). A survey of factors determining the employability of science and technology graduates of polytechnics and universities in the Nigerian labour market. Journal of Science and Technology Education Research, 1(5), 99-106.

Akanmu, O. (2012). Graduate employment and employability challenges in Nigeria. In M. Stiasney \& T. Gore (Eds.), Going global: The landscape for policy makers and practitioners in tertiary education. Bingley: Emerald Group Publishing Limited, (pp. 93-100).

Akerele, W. O., \& Opatola, A. O. (2004). Higher education and the labor market in Nigeria. A Final Report submitted (by NISER) to African Economic Research Consortium. Nairobi, Kenya.

Akindele, F., \& Adegbite, A. (1999). The sociology and politics of English in Nigeria. An introduction. Ile-Ife (Nigeria): OAU Press.

Banjo, A. (1991). On language policy design and implementation. Language Teaching in Today's World. Paris: Hachette.

Banjo, A. (1996). Making a virtue of necessity: An overview of the English language in Nigeria. Ibadan (Nigeria): Ibadan University Press. 
Brown, H. D. (1994). Principles of language learning and teaching. Englewood Cliffs, NJ: Prentice Hall.

Corder, S. P. (1967). The significance of learners' errors. International review of Applied Linguistics, 5, 161-170. In J. C. Richards (Ed.), Error Analysis: Perspectives on Second Language Acquisition. London, UK: Longman.

Corder, S. P. (1971). Idiosyncratic dialects and error analysis. IRAL, 9(2), 147-160. https://doi.org/10.1515/iral.1971.9.2.147

Council for Industry and Higher Education (2008). Graduate employability: What do employers think and want? Will Archer and Jess Davison. Retrieved http://aces.shu.ac.uk/employability/resources/0802Grademployability.pdf

Crossly, S. A., \& McNamara, D. S. (2012). Predicting second language writing proficiency: the roles of cohesion and linguistic sophistication. Journal of Research in Reading, 35(2), 115-135. https://doi.org/10.1111/j.1467-9817.2010.01449.x

Crystal, D. (2003). English as a Global Language (2nd Ed.). Cambridge, UK: Cambridge University Press. https://doi.org/10.1017/CBO9780511486999

Fisher, B. (2010). English Language Quantitative Indicators: Nigeria. A Presentation Made by the British Council Director of Programmes at the National Conference on English Language Teaching held at the Federal Ministry of Education, Abuja, 30 November, 2010.

Jarvis, S., Grant, L., Bikowski, D., \& Ferris, D. (2003). Exploring multiple profiles of highly rated learner compositions. Journal of Second Language Writing, 12(4), 377-403. https://doi.org/10.1016/j.jslw.2003.09.001

Jowitt, D. (2013). English in Nigeria Today: Some Trends Discerned. Journal of the Nigeria English Studies Association (JNESA), 16(1), 1.

Kim, J. (2014). Predicting L2 writing proficiency using linguistic complexity measures: A corpus-based study. English Teaching, 69(4), 27-51. https://doi.org/10.15858/engtea.69.4.201412.27

Lim, H. E. (2010). Predicting low employability graduates: The case of universiti Utara Malaysia. The Singapore Economic Review, 55(3), 523-535. https://doi.org/10.1142/S0217590810003870

Ojeifo, E. (2015). Certified illiterates and unemployable graduates. The Guardian Newspapers, $5^{\text {th }}$ November, 2015. Retrieved $1^{\text {st } J u n e, ~} 2017$ from: https:/guardian.ng/features/certificated-illiterates-and-unemployable-graduates/

Olusoji, M. O., \& Magbagbelola, N. O. (2005). Empirical analysis of labor market demand in Nigeria. Journal of Research in National Development, 3(1), 63-74.

Pitan, O. S. (2015). An assessment of generic skills demand in five sectors of the Nigerian labor market. Public and Municipal Finance, 4(1), 28-36.

Pitan, O. S. (2010). Assessment of skills mismatch among employed university graduates in Nigeria labour market. $\mathrm{Ph}$. D. dissertation. Nigeria: University of Ibadan.

Pitan, O. S., \& Adedeji, S. O. (2012). Skills mismatch among university graduates in Nigeria labor market. US - China Education Review, 2(1), 90-98.

Schneider, E. (2007). Postcolonial English. Cambridge, UK: Cambridge University Press. https://doi.org/10.1017/CBO9780511618901

Sodipo, O. O. (2014). Employability of tertiary education graduates in Nigeria: Closing the skills-gap. Global Journal of Human Resource Management, 2(3), 28-36.

Sompong, M. (2014). Error analysis. Thammasat Review, 6(2), 109-127.

Spencer, J. (ed.) (1971). The English language in West Africa. London, UK: Longman.

Silva, T. (1993). Toward an understanding of the distinct nature of L2 writing: The ESL research and its implications. TESOL Quarterly, 27(4), 657-77. https://doi.org/10.2307/3587400

Taiwo, R. (2009). The functions of English in Nigeria from the earliest times to the present day. English Today, 25(2), 3-10. https://doi.org/10.1017/S0266078409000121

Vanguard Newspaper Online (August 10, 2015). WEAC releases results, with 39\% pass in Eng/Maths. (Retrieved $30^{\text {th }}$ May, 2017).

http://www.vanguardngr.com/2015/08/waec-releases-results-with-38-68-pass-in-engmaths/

http://www.tradingeconomics.com/nigeria/population 